Article

\title{
Soil Chemical and Microbial Properties in a Mixed Stand of Spruce and Birch in the Ore Mountains (Germany) - A Case Study
}

\author{
Karoline Schua ${ }^{1,2, *}$, Stefan Wende ${ }^{1}$, Sven Wagner ${ }^{3}$ and Karl-Heinz Feger ${ }^{1}$ \\ 1 TU Dresden, Institute of Soil Science and Site Ecology, Pienner Straße 19, 01737 Tharandt, \\ Germany; E-Mails: stefan.wende83@gmail.com (S.W.); fegerkh@forst.tu-dresden.de (K.-H.F.) \\ 2 Southern Swedish Forest Research Centre, Swedish University of Agricultural Sciences, Box 49, \\ 23053 Alnarp, Sweden \\ 3 TU Dresden, Institute of Silviculture and Forest Protection, Pienner Straße 8, 01737 Tharandt, \\ Germany; E-Mail: wagner@forst.tu-dresden.de
}

* Author to whom correspondence should be addressed; E-Mail: Karoline.Schua@tu-dresden.de; Tel.: +49-3520-3383-1307.

Academic Editors: Philip J. Polglase and Eric J. Jokela

Received: 19 January 2015 / Accepted: 21 May 2015 / Published: 1 June 2015

\begin{abstract}
A major argument for incorporating deciduous tree species in coniferous forest stands is their role in the amelioration and stabilisation of biogeochemical cycles. Current forest management strategies in central Europe aim to increase the area of mixed stands. In order to formulate statements about the ecological effects of mixtures, studies at the stand level are necessary. In a mixed stand of Norway spruce (Picea abies (L.) KARST.) and silver birch (Betula pendula RoTH) in the Ore Mountains (Saxony, Germany), the effects of these two tree species on chemical and microbial parameters in the topsoil were studied at one site in the form of a case study. Samples were taken from the O layer and A horizon in areas of the stand influenced by either birch, spruce or a mixture of birch and spruce. The microbial biomass, basal respiration, metabolic quotient, $\mathrm{pH}$-value and the $\mathrm{C}$ and $\mathrm{N}$ contents and stocks were analysed in the horizons Of, Oh and A. Significantly higher contents of microbial $\mathrm{N}$ were observed in the Of and Oh horizons in the birch and in the spruce-birch strata than in the stratum containing only spruce. The same was found with respect to $\mathrm{pH}$-values in the Of horizon and basal respiration in the Oh horizon. Compared to the spruce stratum, in the birch and spruce-birch strata, significantly lower values were found
\end{abstract}


for the contents of organic $\mathrm{C}$ and total $\mathrm{N}$ in the A horizon. The findings of the case study indicated that single birch trees have significant effects on the chemical and microbial topsoil properties in spruce-dominated stands. Therefore, the admixture of birch in spruce stands may distinctly affect nutrient cycling and may also be relevant for soil carbon sequestration. Further studies of these functional aspects are recommended.

Keywords: birch; spruce; tree species effects; pH-value; soil respiration; humus; topsoil

\section{Introduction}

In central Europe, pure coniferous stands are today viewed very critically, whereas mixed stands are recommended for a variety of reasons. The establishment of mixed stands of Norway spruce (Picea abies (L.) KARST.) and naturally regenerated silver birch (Betula pendula RoTH) and downy birch (Betula pubescens EHRH.) is a common alternative to pure stands of conifers in northern Europe and Asia (e.g., Finland, Norway, Sweden, Russia), but also in central Europe (e.g., Germany, Poland, Czech Republic). Reasons for the growing interest in such stands are, for example, a shift to a greater above-ground nutrient content associated with species grown in mixtures compared to monocultures, indicating an increase in the proportion of resources captured from a site [1], discussions about biodiversity, such as understorey vegetation diversity (e.g., [2]), sequestration of carbon against the background of climate change (e.g., [3]) and forest growth and yield (e.g., [4]). The growth and vitality of trees are dependent on soil conditions, just as soil development is affected by tree species and forest stand type (e.g., [5-8]). Research has been conducted to examine topsoil properties in pure stands of silver birch and Norway spruce [9-13] and the impact of mixed leaf litter on topsoil has also been studied (e.g., $[10,14])$. On sites with silver birch and Norway spruce, higher $\mathrm{pH}$ values are frequently observed under birch (e.g., [10-12,15]). Several studies also identified lower $\mathrm{C} / \mathrm{N}$ ratios (indicating faster litter decomposition and soil organic matter turnover) in mixed spruce-birch stands than in pure spruce forests (e.g., [12]). In contrast, Hagen-Thorn et al. [13] detected no significant differences between the C/N ratios in the mineral topsoils of 30-40 year old birch and spruce stands. The approaches, conditions and results of different studies are very diverse. The diversity in the results may be related to site conditions (e.g., texture, soil type and climate), stand ages, prior land-use or to the methods employed.

Studies with a focus on soil biological activity (e.g., [16-18]) provided important information on the impact of birch in spruce stands. It appears that birch has a positive influence on microbial biomass and on the mass of earthworms, and also affects the structure of microbial communities [10,17,19], for example, through the influence of birch leaves [10]. The importance of stand age should also be noted in this context, not only as it influences tree dimensions, but also in relation to the duration of the influence of the trees on topsoil properties (e.g., [16]). Examining biological activity, Miles [16] detected higher numbers of earthworms per $\mathrm{m}^{2}$ in medium aged and older stands of Betula pendula in Scotland than in young stands. Saetre et al. [17] found higher densities of Coleoptera, Diptera and Colembola in mixed stands than in spruce stands. This is important as soil biota play a key role in the decomposition of litter (e.g., [20-22]). Animal communities are also strongly affected by tree species (e.g., [23]). Priha et al. [18] presented data from studies of birch and spruce plots where the content of microbial 
carbon $\left(\mathrm{C}_{\mathrm{mic}}\right)$ revealed by fumigation extraction was generally higher under birch than under spruce, but these differences were not significant. At present, it is not possible to draw conclusions on how a mixture of birch and spruce should be designed in order to exert certain effects on the topsoil properties. To address this important question, it appears reasonable to first analyse the effects of single trees. Through the analysis of the effects on topsoil properties of single birch trees in spruce-dominated stands carried out as part of this study, we sought to test the following hypothesis:

- Even single birch trees in spruce stands can modify topsoil properties.

\section{Methods}

\subsection{Study Site}

The study object was a mixed stand of Norway spruce and silver birch on "old" forest soil in the Ore Mountains near Olbernhau/Ansprung, Saxony, Germany (50 $\left.38^{\prime} \mathrm{N}, 13^{\circ} 17^{\prime} \mathrm{E}\right)$. The investigated stand was situated at 725 to $740 \mathrm{~m}$ asl with a slight northerly exposition $(<5 \%)$. The mean annual rainfall was $977 \mathrm{~mm}$ and the mean annual temperature $5.8^{\circ} \mathrm{C}$ (period 2002-2008; source: Staatsbetrieb Sachsenforst). The stand consisted of Norway spruce with an age of approx. 60-80 years and was supplemented to the south by individual silver birch trees, as well as small and large group mixtures with an age of $\sim 60$ years (Table 1).

Table 1. Description of the spruce-birch stand studied in the Ore Mountains, Germany.

\begin{tabular}{|c|c|c|c|c|c|c|c|c|}
\hline Species & $\begin{array}{c}\text { Age } \\
\text { (years) }\end{array}$ & $\mathrm{Nha}^{-1}$ & $\begin{array}{l}\text { dbh } \\
(\mathrm{cm})\end{array}$ & $\begin{array}{c}\text { Basal area } \\
\left(\mathrm{m}^{2} \mathrm{ha}^{-1}\right)\end{array}$ & $\begin{array}{c}\text { Mixture } \\
\text { proportion }\end{array}$ & $\begin{array}{l}\mathrm{H} / \mathrm{D} \\
\text { ratio } \\
\end{array}$ & $\begin{array}{l}\text { Volume } \\
\left(\mathrm{m}^{3} \mathrm{ha}^{-1}\right)\end{array}$ & $\begin{array}{l}\text { Crown } \\
\text { percent }\end{array}$ \\
\hline Spruce & 60 to 80 & 453 & 29 & 32.0 & 92.6 & 69 & 330 & 60 \\
\hline Birch & 60 & 36 & 30 & 2.6 & 7.4 & - & 25 & 48 \\
\hline
\end{tabular}

dbh, diameter at breast height; $\mathrm{H}$, height; $\mathrm{D}$, diameter; $\mathrm{N}$ : Number of trees (per hectare).

The spruce was planted with the aim of establishing a pure stand. Birch regenerated naturally in gaps where spruce planting failed. In areas with more birch trees, the soil had a higher stone content and was not comparable to that of the plots with spruce. For the purposes of the analysis, only single birches situated where the soil properties were comparable to those of spruce plots were selected. The study stand was surrounded by spruce stands. Some isolated beech trees stood in the neighbouring stands, but these were situated far from the chosen study points and could not influence the results. In the neighbouring stands, typical admixed species were birches and mountain-ash (Sorbus aucuparia L.). In densely stocked areas of the study stand, ground vegetation was absent or only poorly developed. Even in sparsely stocked, unshaded areas the ground vegetation was not lush or densely developed. The dominant species were Calamagrostis villosa and Deschampsia flexuosa.

The soil was typical of many mid-range mountains in central Europe: a Dystric Cambisol formed from periglacial debris layers consisting of the weathered products of a gneiss bedrock. The soil chemistry was characterised by high acidity, a low cation exchange capacity and base saturation. The stone content was very high (Table 2). 
Table 2. Description of the soil physical and chemical properties for the study site (samples came from an extra soil profile created for the characterisation of the study site), n.a. $=$ not analysed.

\begin{tabular}{|c|c|c|c|c|c|c|c|}
\hline \multirow[t]{2}{*}{ Horizon } & Depth & $\begin{array}{c}\text { Dry bulk } \\
\text { density (fine soil) }\end{array}$ & Stone content & pH-value & $\mathrm{C}_{\text {org }} / \mathrm{N}$ ratio & $\mathbf{C E C}_{\text {eff }}$ & BS \\
\hline & $(\mathrm{cm})$ & $\left(g^{*} \mathrm{~cm}^{-3}\right)$ & $(\operatorname{mass} \%)$ & $\mathrm{H}_{2} \mathrm{O}$ & $(-)$ & $\left(\mu \mathrm{eq} \mathrm{g}^{-1}\right)$ & $(\%)$ \\
\hline $\mathrm{L}$ & +3.5 to +4 & n.a. & n.a. & n.a. & n.a. & n.a. & n.a. \\
\hline Of & +2 to +3.5 & 0.15 & 0 & 5.04 & 20 & 1625.37 & 98.3 \\
\hline $\mathrm{Oh}$ & 0 to +2 & 0.28 & 0 to 28 & 5.02 & 16 & 1938.12 & 99.3 \\
\hline Ahe/Ae & 0 to 11 & 0.83 & 36 & 3.94 & 18 & 415.05 & 57.0 \\
\hline Bsh/Bhs & 11 to 17 & 0.51 & 50 & 3.87 & 23 & 68.29 & 9.4 \\
\hline $\mathrm{Bv}$ & 17 to 32 & 0.80 & 41 & 4.47 & 19 & 41.68 & 6.0 \\
\hline $\mathrm{Bv} / \mathrm{Cv}$ & $32+$ & n.a. & n.a. & 4.63 & 13 & 135.48 & 17.5 \\
\hline
\end{tabular}

CECeff=effective cation exchange capacity; Corg=organic Carbon; L $=$ Litter; Of $=$ Organic layer with fermentation; $\mathrm{Oh}=$ humified organic layer $=$ strongly decomposed organic matter; Ahe = uppermost horizon of the mineral soil enriched with soil organic matter and characterized by eluviation (bleached by podzolization); $\mathrm{Ae}=$ mineral horizon of the topsoil characterized by eluviation; $\mathrm{Bsh} / \mathrm{Bhs}=$ mineral subsoil horizon with Fe/Al-enrichment (sesquioxides) by podzolization and with humus accumulation; $\mathrm{Bv}=$ mineral subsoil horizon, weathered, brown and loamy; $\mathrm{Cv}$ = weakly weathered parent material

\subsection{Experimental Design}

The approach adopted aimed at investigating the ecological impact of incorporating birch trees into spruce stands, by identifying areas influenced mostly by birch, both by birch and spruce and mostly by spruce trees. Thirty sample plots were assigned to the different strata, according to the species occupying the canopy overhead. All sample points that lay directly beneath the crown of a birch were assigned to the birch stratum $(n=7)$. Points under the crowns of spruce trees were assigned to the spruce stratum $(n=13)$. All points located between the crown of a birch and a spruce, and where crowns overlapped, were assigned to the spruce-birch stratum $(n=10)$. This stratification was used because crowns directly influence the environmental variables (e.g., precipitation throughfall), which in turn affect topsoil properties (e.g., [24,25]). The ecological effects could be measured in terms of their quality and intensity. Usually a gradient in the intensity, and also the quality, of the effects coinciding with the distance from the birch tree can be expected. In stands with more than one tree species, the overlapping zones of the different tree species' effects are of particular interest. In these zones, different litter mixtures exist. This means that two tree species influence the topsoil conditions to different degrees of intensity. Three different tree-to-tree-transects were laid out for this study. All of the transects originated at the same birch tree (Figure 1) and pointed in different directions, representing various tree species mixture gradients. A total of 30 sampling points were then clustered according to whether they were mostly influenced by either birch or spruce trees, or by a mixture of both species. Four different birch trees influenced the sampling sites to varying degrees. The size of the study area within the chosen stand was circa 0.4 ha.

This study was designed as a case study so that further investigations are needed for generalisation of the results beyond the study site. The focus of this study was on an intra-stand level approach for the following reasons:

The intra-stand level was deemed to be an appropriate spatial scale at which to optimise the forest 
structure in plantation forests in order to address new challenges as timber production, neighbour competition and nutrient cycle processes all take place at this scale [26].

Single trees are key structural elements of a stand as species, dimension, morphology and the spatial distribution of single trees influence the biotic and abiotic conditions of the intra-stand environment, in particular the understorey vegetation and the topsoil properties (e.g., [27-32]).

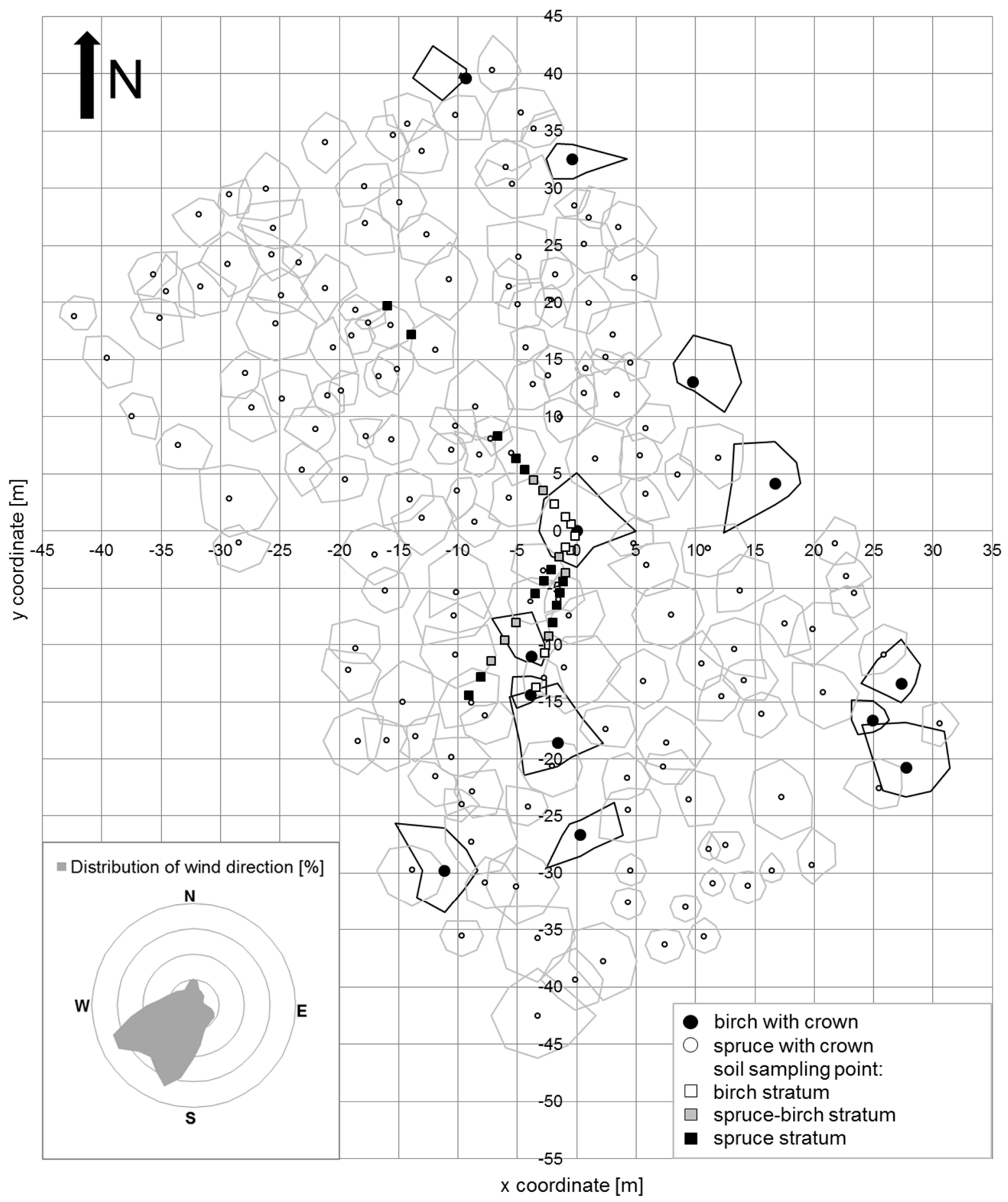

Figure 1. Map of tree stems and crowns with soil sampling points indicated along transects with percental distribution of the wind direction (01.01.1997-31.05.2009) measured at the Olbernhau permanent monitoring area (Staatsbetrieb Sachsenforst); average wind speed: $1.51 \mathrm{~m} \mathrm{~s}^{-1}$, maximum wind speed: $6.41 \mathrm{~m} \mathrm{~s}^{-1}$. 


\subsection{Soil Sampling and Analysis}

To ensure relatively homogeneous soil conditions along the transects, sample points $(30 \mathrm{~cm} \times 30 \mathrm{~cm})$ were selected where there were no disturbances (e.g., lying trunks, stumps). Therefore, the distance between the points along the transects was variable (mean distance within one transect $=2.03 \mathrm{~m}$, minimum distance $=0.73 \mathrm{~m}$, maximum distance $=11.5 \mathrm{~m}$ ). In early September 2008, 90 soil samples were taken from the forest floor (30 samples of Of and 30 samples of Oh horizons) and mineral topsoil (30 samples of A horizon) for chemical analysis in the laboratory.

Fresh soil samples were sieved with a $5 \mathrm{~mm}$ sieve for removal of components such as branches, roots and stones. The soil $\mathrm{pH}$ was measured in water $\left(50 \mathrm{~mL}\right.$ demineralised pure $\mathrm{H}_{2} \mathrm{O}$ and $10 \mathrm{~mL}$ dried soil (dried at $40{ }^{\circ} \mathrm{C}$ )) with a glass electrode (Multilab $540 \mathrm{WTW} \mathrm{GmbH}$ ). The total $\mathrm{C}$ and $\mathrm{N}$ contents of ground soil samples were measured using the CNS elemental analyser (Vario EL). As the soil had been limed in the past, the total carbon $\left(\mathrm{C}_{\text {tot }}\right)$ may not have equalled the organic $\mathrm{C}\left(\mathrm{C}_{\mathrm{org}}\right)$. Therefore, $\mathrm{C}_{\text {carbonate }}$ was also analysed using the gas-volumetric method according to Scheibler (Deutsches Institut für Normung e. V. (DIN) International Organization for Standardization (ISO) 10693). Organic C was calculated as the difference between $\mathrm{C}_{\text {tot }}$ and $\mathrm{C}_{\text {carbonate. The }} \mathrm{C} / \mathrm{N}$ ratio was calculated by dividing $\mathrm{C}_{\text {org }}$ by $\mathrm{N}_{\text {tot. }}$. Carbon and nitrogen in the microbial biomass $\left(\mathrm{C}_{\text {mic }}\right.$ and $\left.\mathrm{N}_{\text {mic }}\right)$ were analysed using chloroform-fumigation-extraction according to Vance et al. [33] and Joergensen [34]. The samples were sieved and analysed fresh. They were not frozen, but cooled to around $4{ }^{\circ} \mathrm{C}$ for a maximum of 18 days before the analyses began. After fumigation, shaking with $\mathrm{K}_{2} \mathrm{SO}_{4}$ solution for 30 minutes with 180 rotations $\mathrm{min}^{-1}$ and filtration, the $\mathrm{C}$ and $\mathrm{N}$ contents were determined with the Multi-NC-Analyser (Analytik Jena). To represent the soluble part of $\mathrm{C}$ and $\mathrm{N}, \mathrm{C}$ and $\mathrm{N}$ were also extracted from unfumigated soil [33]. In accordance with Jenkinson et al. [35], a correction factor of 0.45 was used in the denominator when calculating $\mathrm{C}_{\text {mic }}$ and $\mathrm{N}_{\text {mic }}$. The basal respiration was determined using the method described by Isermeyer [36] and modified in accordance with Jäggi [37]. To describe the soil profile, the effective cation exchange capacity $\left(\mathrm{CEC}_{\text {eff }}\right)$ was analysed based on the $\mathrm{NH}_{4} \mathrm{Cl}$ extraction method developed by Trüby and Aldinger [38]. To calculate the stocks of $\mathrm{C}_{\mathrm{org}}, \mathrm{N}_{\text {tot }}, \mathrm{C}_{\text {mic }}$ and $\mathrm{N}_{\text {mic }}$, the soil bulk densities were determined based on undisturbed soil cores taken using soil sample rings (for the $\mathrm{O}$ layer: sampling rings with a diameter of $7.2 \mathrm{~cm}$ and a volume of $248.4 \mathrm{~cm}^{2}$, for the mineral sampling rings with a diameter of $5.5 \mathrm{~cm}$ and a volume of $95 \mathrm{~cm}^{2}$ ). The samples were dried at $60{ }^{\circ} \mathrm{C}$ (forest floor) and $105{ }^{\circ} \mathrm{C}$ (mineral soil) for $24 \mathrm{~h}$. The thickness of the sampled soil horizons was the average of three measurements around the soil cores. The mean thicknesses of the Of and Oh horizons in the three different strata were: birch: $\mathrm{Of}=0.97 \mathrm{~cm}, \mathrm{Oh}=1.83 \mathrm{~cm}$, spruce-birch: $\mathrm{Of}=1.23 \mathrm{~cm}, \mathrm{Oh}=2.47 \mathrm{~cm}$ and spruce: $\mathrm{Of}=1.30 \mathrm{~cm}, \mathrm{Oh}=2.40 \mathrm{~cm}$. Coarse material was removed using a $2 \mathrm{~mm}$ mesh and the mass fraction of the horizon area $\left(\mathrm{g} \mathrm{m}^{-2}\right)$ was determined.

\subsection{Statistical Analysis}

An extended linear model without random effects was applied to the data. The model validation process outlined by Zuur et al. ([39]; p19-p21) was followed and the normality, the homogeneity and the independence in the dataset assessed. To be certain of normality, all residuals of the applied model were pooled and their distribution inspected (by q-q-plots). Heteroscedasticity was assessed by pooling 
all residuals and plotting them against the fitted values. Where heteroscedasticity was an issue, the model was adapted to account for the variance structure of the data. The spatial independence of the data was assessed employing the semivariogram technique ([40]; p. 226). Where necessary, a spatial dependence structure was incorporated in the model. P-values were adjusted in simultaneous multiple testing by applying the Benjamini-Hochberg procedure ([41]; p. 534). As natural heterogeneity is high in forest soils, and the sample size low, an error probability of $\alpha=0.10$ was applied and the significant differences observed are reported and discussed as trends. An error probability of $\alpha=0.10$ is frequently used for studies of microbial properties in soils (e.g., [42-44]). All statistical analyses were performed using R and boxplots were created with SPSS.

\section{Results}

\subsection{Carbon}

Significant differences in the $\mathrm{C}_{\text {org }}$ content occurred between the tree strata in the A horizon (Figure 2a). Here birch $<$ spruce $\left(p=0.066\right.$; medians: $\left.71 \mathrm{mg} \mathrm{g}^{-1}<118 \mathrm{mg} \mathrm{g}^{-1}\right)$ and spruce-birch $<$ spruce with ( $p=0.066$; medians: $103 \mathrm{mg} \mathrm{g}^{-1}<118 \mathrm{mg} \mathrm{g}^{-1}$ ). A decrease in the $\mathrm{C}_{\text {org }}$ content was observed from the Of horizon to the A horizon.

The $\mathrm{C}_{\text {org }}$ stocks (Figure $2 \mathrm{~b}$ ) did not differ between the three strata within each horizon analysed. The highest values were found in the Oh horizon and the lowest in the A horizon.

\subsection{Nitrogen}

No significant differences existed for the $\mathrm{N}_{\text {tot }}$ contents in the Of and Oh horizons (Figure 2c). $\mathrm{N}_{\text {tot }}$ contents were lowest in the A horizon, where they differed significantly between the three strata, with birch $<$ spruce $\left(p=0.087\right.$; medians: $\left.4.24 \mathrm{mg} \mathrm{g}^{-1}<6.06 \mathrm{mg} \mathrm{g}^{-1}\right)$ as well as spruce-birch $<$ spruce ( $p=0.087$; medians: $5.45 \mathrm{mg} \mathrm{g}^{-1}<6.06 \mathrm{mg} \mathrm{g}^{-1}$ ).

There were no significant differences in the Of, Oh or A horizons between the strata for the $\mathrm{N}_{\text {tot }}$ stocks (Figure $2 \mathrm{~d}$ ). The $\mathrm{N}_{\text {tot }}$ stocks were higher in the Oh horizon than in the Of and the A horizons.

\section{3. $C / N$ Ratio and Acidity}

No noticeable differences were found for the $\mathrm{C} / \mathrm{N}$ ratio (Figure $2 \mathrm{e}$ ). It was notable that the $\mathrm{C} / \mathrm{N}$ ratios in the Oh horizon were lower than in either the Of horizon or the A horizon.

The Of horizon exhibited a significantly higher $\mathrm{pH}$-value (Figure $2 \mathrm{f}$ ) in the birch stratum (median = 5.41) than in the spruce (median $=5.12$ ) with $p=0.086$, and in the spruce-birch stratum (median $=5.49)$ than in the spruce with $p=0.086$. No noticeable differences were found in the Oh and A horizons. The highest $\mathrm{pH}$-values were found in the Oh horizon, the lowest in the A horizon.

\subsection{Microbial Properties}

The results of the analysis of $\mathrm{C}_{\text {mic }}$ contents (Figure $3 \mathrm{a}$ ) revealed no notable differences in all three horizons. $\mathrm{C}_{\text {mic }}$ contents decreased from the Of horizon to the A horizon.

In the $\mathrm{O}$ layer, the lowest $\mathrm{N}_{\text {mic }}$ contents were found in areas where only spruce had an impact 
(Figure $3 b$ ). The $\mathrm{N}_{\text {mic }}$ contents in the Of horizon differed significantly for birch and spruce-birch ( $p=0.098$; medians: $\left.0.35 \mathrm{mg} \mathrm{g}^{-1}>0.25 \mathrm{mg} \mathrm{g}^{-1}\right)$ and for spruce-birch and spruce $(p=0.098$; medians: $\left.0.35 \mathrm{mg} \mathrm{g}^{-1}>0.22 \mathrm{mg} \mathrm{g}^{-1}\right)$. In the Oh horizon differences were observed for birch and spruce $(p=0.096$; medians: $\left.0.20 \mathrm{mg} \mathrm{g}^{-1}>0.14 \mathrm{mg} \mathrm{g}^{-1}\right)$ and for spruce-birch and spruce $(p=0.096$; medians: $0.16 \mathrm{mg} \mathrm{g}^{-1}>0.14 \mathrm{mg} \mathrm{g}^{-1}$ ). No clear differences between the strata existed with respect to the A horizon.

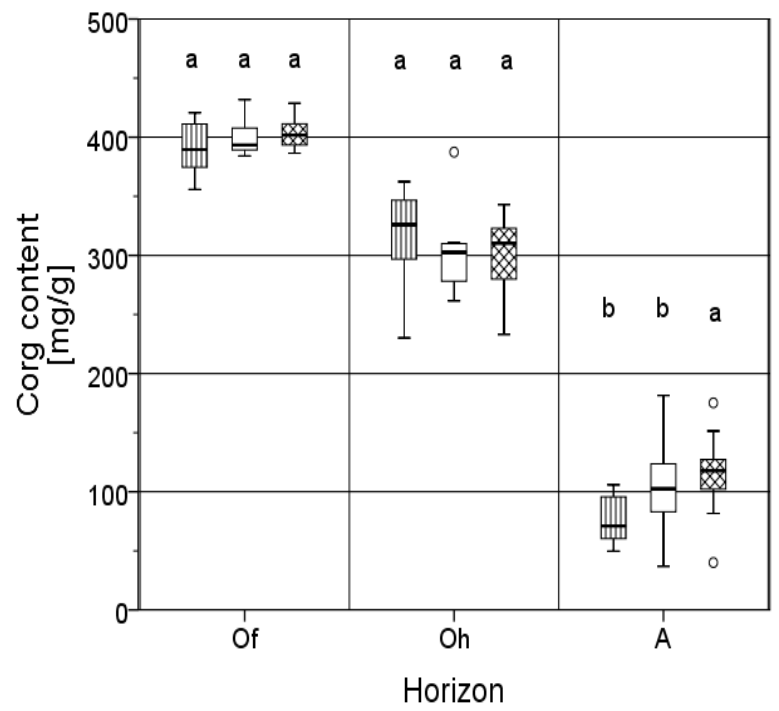

(a)

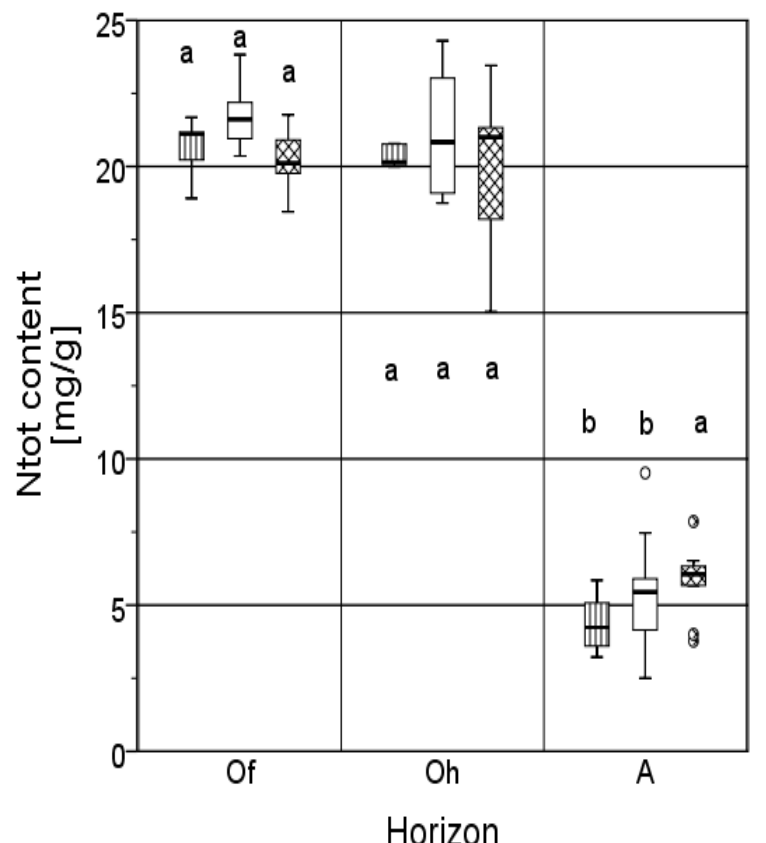

(c)

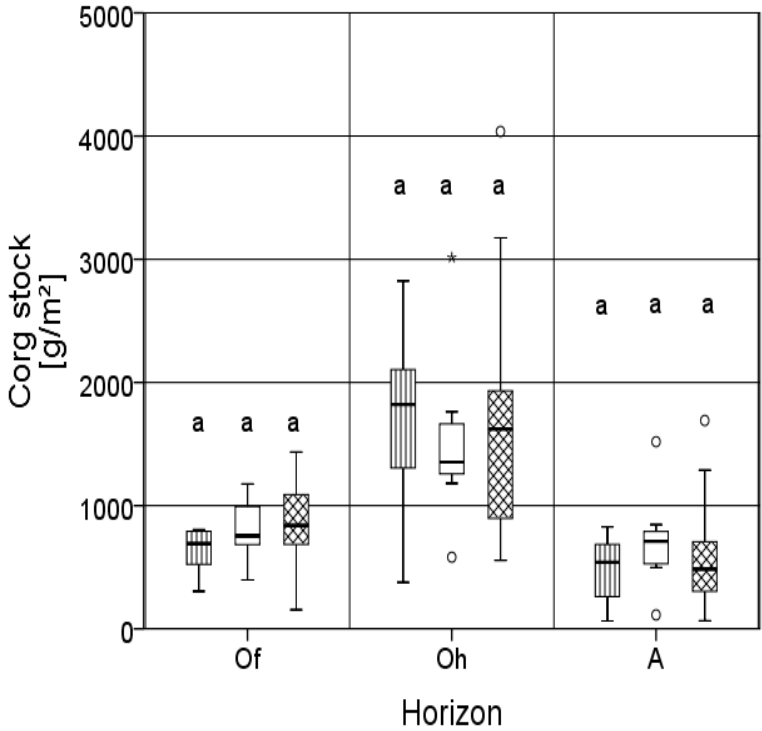

(b)

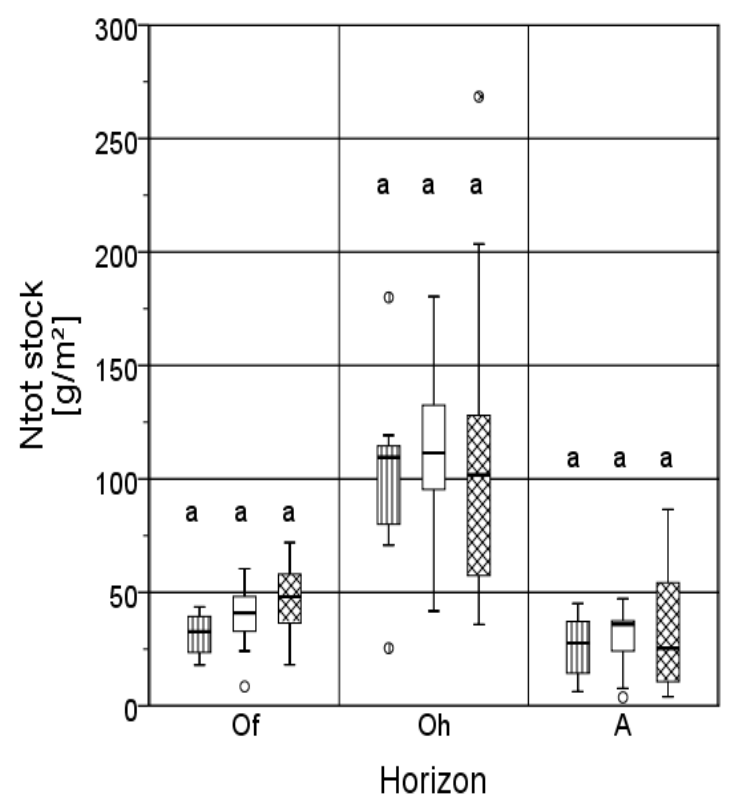

(d)

Figure 2. Cont. 


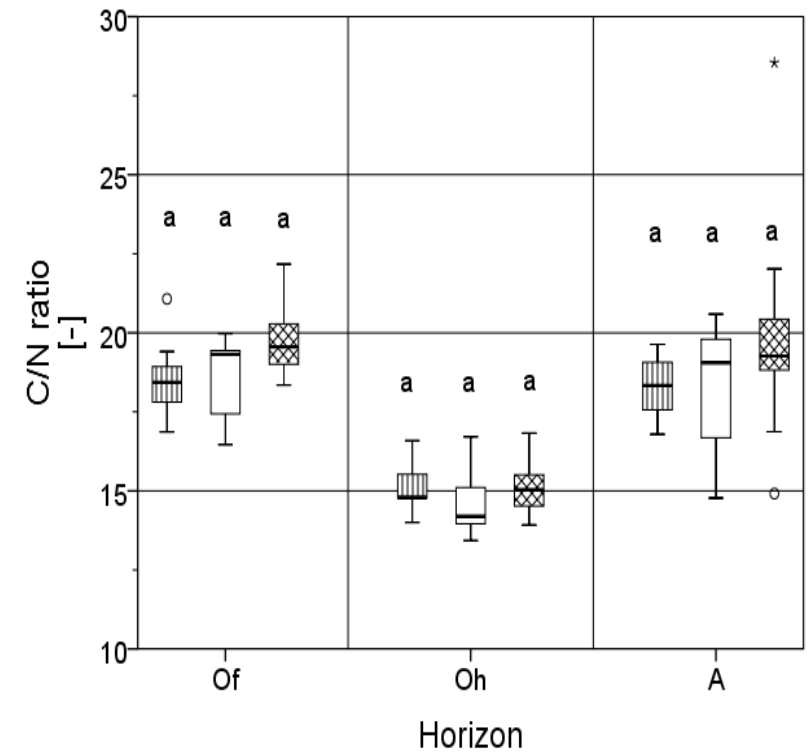

(e)

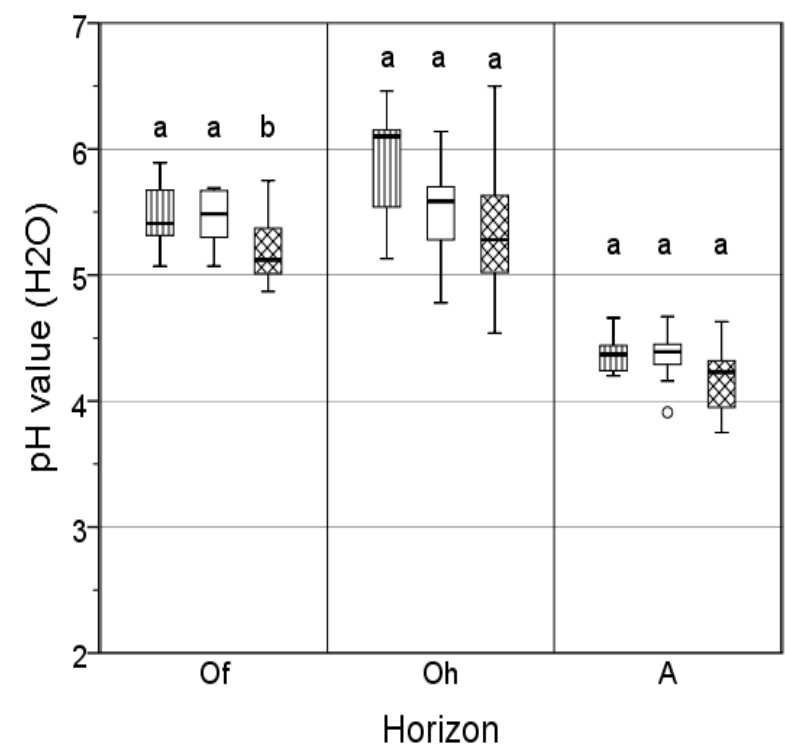

(f)

Figure 2. Box-whisker-plots for the tree strata (dashed: birch stratum, white: spruce-birch stratum, chequered: spruce stratum) in the three horizons depicting (a) organic $\mathrm{C}$ content; (b) organic $\mathrm{C}$ stock; (c) total $\mathrm{N}$ content; (d) total $\mathrm{N}$ stock; (e) $\mathrm{C} / \mathrm{N}$ ratio and (f) $\mathrm{pH}\left(\mathrm{H}_{2} \mathrm{O}\right)$. Different lower case letters indicate significant differences between strata within one horizon $(p<0.10)$.

Values of the basal respiration (an indicator of microbial activity) decreased from the Of horizon to the A horizon (Figure $3 \mathrm{c}$ ). In the Oh horizon, the lowest microbial activity was found under spruce (spruce $<$ birch; $p=0.071$; medians: $0.03\left(\mathrm{mg} \mathrm{CO}_{2} \mathrm{~h}^{-1}\right) \mathrm{g}^{-1}<0.05\left(\mathrm{mg} \mathrm{CO}_{2} \mathrm{~h}^{-1}\right) \mathrm{g}^{-1}$ and spruce $<$ spruce-birch; $p=0.092$; medians: $\left.0.03\left(\mathrm{mg} \mathrm{CO}_{2} \mathrm{~h}^{-1}\right) \mathrm{g}^{-1}<0.04\left(\mathrm{mg} \mathrm{CO}_{2} \mathrm{~h}^{-1}\right) \mathrm{g}^{-1}\right)$. No significant differences between the strata existed in the Of and A horizons.

The analysis of the metabolic quotient $\left(\mathrm{qCO}_{2}\right)$, an indicator of the $\mathrm{CO}_{2}$ release rate per unit of microbial biomass $\left(\left(\mathrm{mg} \mathrm{CO} 2-\mathrm{C} \mathrm{h}^{-1}\right) \mathrm{g}^{-1} \mathrm{C}\right.$ mic $)$, revealed no significant differences (Figure 3d). The metabolic quotient was highest in the Of horizon, which also had the greatest variation. There the spruce stratum exhibited the second lowest and the birch stratum the lowest values.

\section{Discussion}

Tree species can affect soil properties in different ways; for example, prompting differences in the chemical composition of above- and below-ground litter, differences in root activity and changes in microclimate under the tree cover, changing the understorey vegetation [45]. The aim of this study was to assess whether even single tree admixtures of birch have a distinct effect on topsoil properties in spruce stands. The results of the stratified analysis provided evidence that when silver birch and Norway spruce grew in the same stand, the $\mathrm{pH}$-value in the Of horizon was less than a half unit higher under birch. These findings were consistent with previous studies (e.g., [25,46,47]). Augusto et al. [48] determined that the $\mathrm{pH}$-value of topsoil from the same site is on average about 0.43 units higher under birch than under spruce. A higher $\mathrm{pH}$ of this magnitude could positively affect the microbial biomass in the soil (see below) and the number and mass of earthworms [49]. Such changes in pH may also influence 
the roots of spruce. Both the growth and the morphology of spruce roots depend greatly on soil chemical properties affecting the composition of soil solution [50]. Acid conditions inhibit root growth (e.g., [51]) and lead to fewer fine roots in the mineral soil, and to a concentration of the roots in the O layer (e.g., [52]). The presence of the roots of the two different tree species also affect the soil; for example, through root exudates [53]. Sandnes et al. [53] concluded that the rhizosphere of birch contains more organic acids at higher concentrations than spruce. Higher organic acid production means a higher potential to lower $\mathrm{pH}$, which contradicts our earlier discussion. Due to the differences in the root systems and root distribution of spruce [54,55] and birch [56], different effects on the soil are likely.

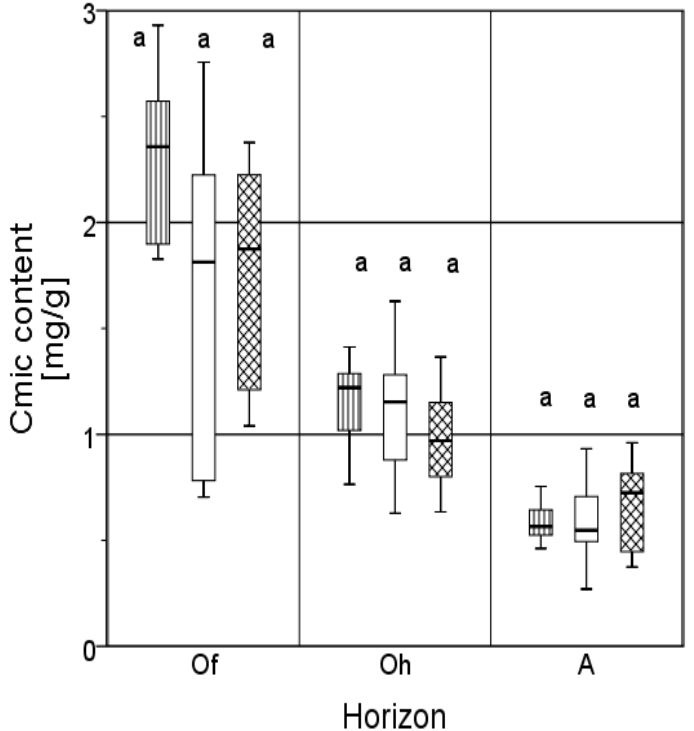

(a)

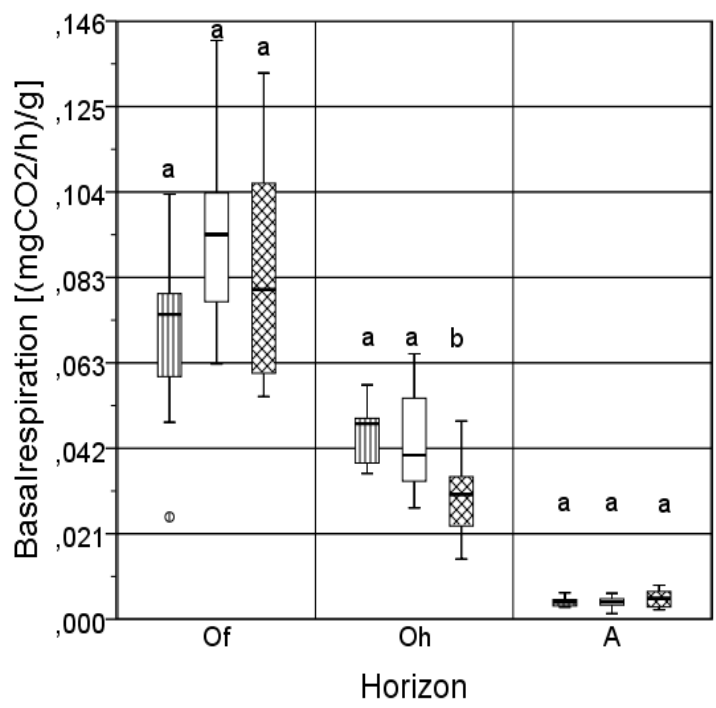

(c)

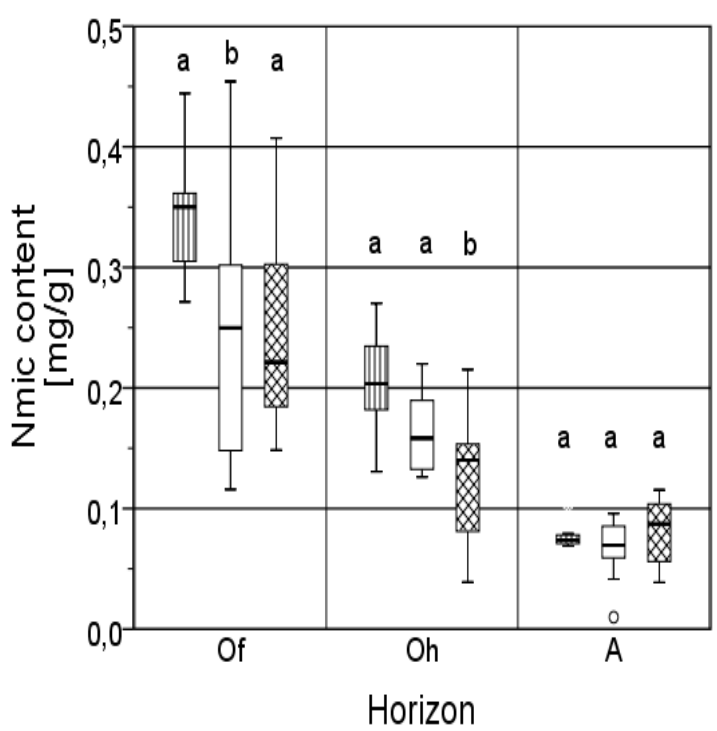

(b)

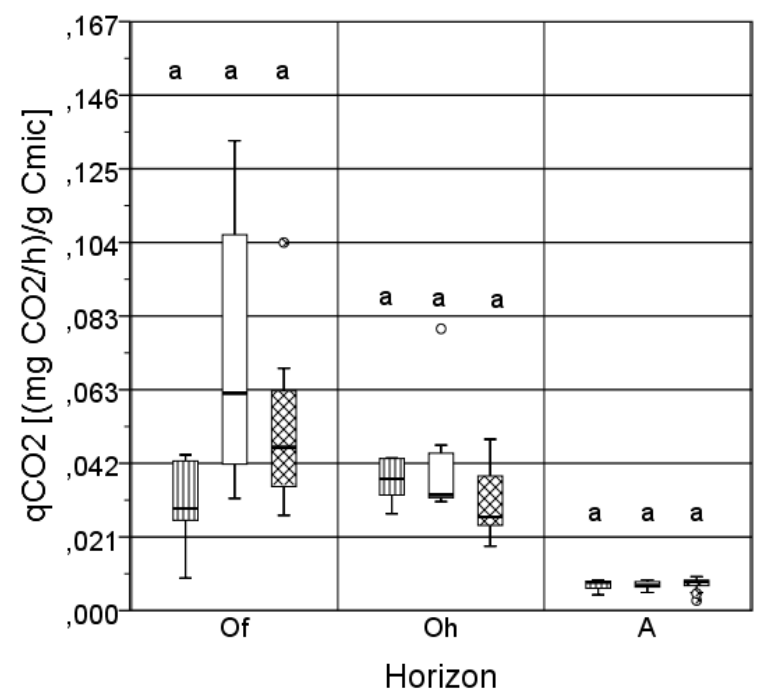

(d)

Figure 3. Box-whisker-plots of the tree strata (dashed: birch stratum, white: spruce-birch stratum, chequered: spruce stratum) in the three horizons depicting (a) microbial C content; (b) microbial $\mathrm{N}$ content; (c) basal respiration and (d) metabolic quotient $\left(\mathrm{qCO}_{2}\right)$. Different lower case letters indicate significant differences between strata within one horizon $(p<0.10)$. 
The $\mathrm{C} / \mathrm{N}$ ratio is an important indicator of the transformation of soil organic matter. The observation that $\mathrm{C} / \mathrm{N}$ ratios were generally lower in the birch and spruce-birch strata than in the spruce stratum corresponded to the results of several earlier studies (e.g., [10,12,57-59]). Material with a lower C/N ratio can be decomposed by microorganisms much more readily. However, in this study the differences between the strata were not significant.

The $\mathrm{N}_{\text {tot }}$ contents of the $\mathrm{Of}$ and $\mathrm{Oh}$ horizons exhibited no significant differences, whereas in the $\mathrm{A}$ horizon the values were significantly higher for the spruce stratum than for the birch and spruce-birch strata. Priha and Smolander [60] also found lower $\mathrm{N}_{\text {tot }}$ contents under a birch stand than a neighbouring even-aged spruce stand. However, the findings of our study deviated from those of certain other studies such as Lettl and Hysek [9] and Brandtberg et al. [11]. Lettl and Hysek [9] found higher $\mathrm{N}_{\text {tot }}$ contents in the Of horizon under spruce but lower contents of $\mathrm{N}_{\text {tot }}$ in the Oh when compared with birch. Brandtberg et al. [11] found no differences between the two species with respect to $\mathrm{N}_{\text {tot }}$ contents in a 20-30 year old spruce-birch stand. This may have been due to the low stand age in their study. Many other studies have produced evidence of a change in soil properties as a function of stand age (e.g., [16,61-63]), time elapsed since the understorey planting of deciduous trees (e.g., [64]) and single tree ages (e.g., [65]). However, in our study, the effects of stand age were not captured at all (stand was even-aged 60-80 years).

The results of our study revealed higher $\mathrm{N}_{\text {mic }}$ contents under the influence of birch than under spruce in the O layer. These results were consistent with Priha et al. [18] and Smolander et al. [66]. An inverse pattern was found for the A horizon in our study and by Smolander et al. [66]. We found greater basal respiration under birch than under spruce in the Oh horizon, similar to Priha et al. [18] and Smolander et al. [66]. Our results support the assumption that the presence of birch might increase microbial biomass $[10,16,19,67]$. In our study, no significant difference between the tree species could be found for the three horizons with respect to the metabolic quotient. This was consistent with the findings of Priha and Smolander [68]. In the A horizon, $\mathrm{C}_{\text {org }}$ contents were lowest in the pure birch stratum and intermediate in the mixed stratum, which corresponded to the lowest $\mathrm{C} / \mathrm{N}$ ratio, reflecting amongst other things the better birch litter quality compared to spruce litter (e.g., [69]). Johansson [70] proved that at sites where Norway spruce and white birch grew in adjacent stands, the birch leaf litter generally had higher nutrient concentrations. Concerning organic chemical components, the spruce needle litter had significantly higher concentrations of lignin and mannan and lower concentrations of water solubles, rhamnan and xylan than the birch litter [70]. Furthermore, Kanerva et al. [47] observed lower concentrations of terpenes under birch in comparison with spruce. In the Oh horizon of our study, the mixed stratum revealed the lowest values of $C_{\text {org }}$ contents (but no significant differences between the strata), indicating a faster turnover of soil organic matter in this horizon. This was not only the effect of litter quality (more favourable for decomposition), as the values in the pure birch stratum were more similar to those of the spruce stratum, but more likely an effect of increased microbial activity, which naturally depends, for example, on litter quality. This may hint at a more diverse and active soil biocoenosis in the Oh horizon in the mixed stratum overall than found in the single-species strata [71]. As a consequence, more organic material is incorporated into the mineral soil in the mixed stratum, which is reflected in the highest Corg stocks in the A horizon of the mixed stratum, although the differences between the strata were not significant. However, some of our results indicate that even single tree admixtures of birch have a distinct effect on topsoil properties in spruce stands. Therefore, 
we accept the hypothesis that even single birch trees in spruce stands can modify topsoil properties. It must be stated in relation to this, however, that our results could have been influenced by factors such as the anisotropy in the distribution of birch litter [32] caused by the main wind direction (south-west, Figure 1), the small-scale variability of throughfall and corresponding differences with respect to water supply (e.g., [72]), the fine root dynamics (e.g., [73]) or the diversity of radiation in the stand and the related differences in soil temperature and light availability for the ground vegetation [32]. These factors influence the variance of data and might lead to less significant differences between the strata.

\section{Conclusions}

The findings of this study show that even single tree admixtures of birch have a distinct effect on topsoil properties in spruce stands. The admixture of single birch trees generates higher $\mathrm{pH}$-values and higher microbial activity in the $\mathrm{O}$ layer. The admixture of single birch trees in spruce stands may also play a role in soil carbon sequestration, because higher microbial activity could lead to lower total soil organic carbon (SOC) stocks in the humus layer but higher and more stable SOC stocks in the mineral soil. Future research should investigate whether the higher biological activity in soils causes greater incorporation of humus into the upper mineral soil and study the pools of stable and unstable organic carbon in spruce-birch mixtures in order to analyse the real potential for carbon sequestration. One might expect that an increase in the number of birch trees leads to an intensification of the observed effects. Another important aspect for future research might be a study of whether different ages of litter affect the different topsoil results (e.g., soil microbial properties) in such mixtures. That is a very interesting question because partly decomposed spruce litter of different ages could be found in the Of horizon (typical for conifers), while birch litter consisted mainly of the leaves from the last autumn (typical for many broadleaves), indicating a different state of decay and thus possibly a different composition of the litter remains. As our findings indicated that single birch trees have significant effects on the chemical and microbial topsoil properties in spruce-dominated stands, the admixture of birch in spruce stands may have a distinct effect on nutrient cycling and may also be relevant for soil carbon sequestration. Consequently, further studies of these functional aspects are recommended.

\section{Acknowledgements}

This research was supported by various funds provided by the Deutsche Bundesstiftung Umwelt (DBU), Staatsbetrieb Sachsenforst, Technische Universität Dresden and the Georg-Ludwig-Hartig Stiftung. We acknowledge support by the German Research Foundation and the Open Access Publication Funds of the TU Dresden. We are indebted to Thomas Klinger, Manuela Unger, Gerlind Mitschick and Ruth Rüger for their support in the analysis of the soil samples. We wish to thank Nils Fahlvik and Christine Knust for their help preparing the manuscript. We would also like to thank the anonymous referees for their constructive comments and suggestions. We are grateful to David Butler Manning for improving the language.

\section{Author Contributions}

Karoline Schua conceived and designed the experiments together with the scientific supervisors Sven 
Wagner and Karl-Heinz Feger. Karoline Schua and Stefan Wende performed the experiments and analysed the data. Karoline Schua wrote the paper with the support of Karl-Heinz Feger and Sven Wagner.

\section{Conflicts of Interest}

The authors declare no conflict of interest.

\section{References}

1. Richards, A.E.; Forrester, D.I.; Bauhus, J.; Scherer-Lorenzen, M. The influence of mixed tree plantations on the nutrition of individual species: A review. Tree Physiol. 2010, 30, 1192-1208.

2. Barbier, S.; Gosselin, F.; Balandier, P. Influence of tree species on understory vegetation diversity and mechanisms involved-A critical review for temperate and boreal forests. For. Ecol. Manag. 2008, 254, 1-15.

3. Jandl, R.M.; Lindner, M.; Vesterdal, L.; Bauwens, B.; Baritz, R.; Hagedorn, F.; Johnson, D.W.; Minkkinen, K.; Byrne, K.A. How strongly can forest management influence soil carbon sequestration? Geoderma 2007, 137, 253-268.

4. Fahlvik, N.; Agestam, E.; Ekö, P.M.; Lindén, M. Development of single-storied mixtures of Norway spruce and birch in Southern Sweden. Scand. J. For. Res. 2011, 26, 36-45.

5. Van Breemen, N.; Finzi, A.C.; Canham, C.D. Canopy tree-soil interactions within temperate forests: Effects of soil elemental composition and texture on species distributions. Can. J. For. Res. 1997, 27, 1110-1116.

6. Finzi, A.C.; van Breemen N.; Canham, C.D. Canopy tree-soil interactions within temperate forests: Species effects on soil carbon and nitrogen. Ecol. Appl. 1998, 8, 440-446.

7. Finzi, A.C.; Canham, C.D.; van Breemen, N. Canopy tree-soil interactions within temperate forests: Species effects on $\mathrm{pH}$ and cations. Ecol. Appl. 1998, 8, 447-454.

8. Samec, P.; Vavř́lček, D.; Šimková, P.; Pňáček, J. Multivariate statistical approach to comparison of the nutrient status of Norway spruce (Picea abies L. Karst.) and top-soil properties in differently managed forest stands. J. For. Sci. 2007, 53, 101-112.

9. Lettl, A.; Hysek, J. Soil microflora in an area where spruce (Picea abies) was killed by $\mathrm{SO}_{2}$ emissions and was succeeded by birch (Betula pendula) and mountain ash (Sorbus aucuparia). Ecol. Eng. 1994, 3, 27-37.

10. Saetre, P. Decomposition, microbial community structure, and earthworm effects along a birch-spruce soil gradient. Ecology 1998, 79, 834-846.

11. Brandtberg, P.O.; Lundkvist, H.; Bengtsson, J. Changes in forest-floor chemistry caused by a birch admixture in Norway spruce stands. For. Ecol. Manag. 2000, 130, 253-264.

12. Brandtberg, P.O.; Lundkvist, H. Does an admixture of betula species in Picea abies stands increase organic matter quality and nitrogen release? Scan. J. For. Res. 2004, 19, 127-141.

13. Hagen-Thorn, A.; Callesen, I.; Armolaitis, K.; Nihlgård, B. The impact of six European tree species on the chemistry of mineral topsoil in forest plantations on former agricultural land. For. Ecol. Manag. 2004, 195, 373-384. 
14. Nilsson, M.C.; Wardle, D.A.; Dahlberg, A. Effects of plant litter species composition and diversity on the boreal forest plant-soil system. Oikos 1999, 86, 16-26.

15. Brandtberg, P.O.; Simonsson, M. Aluminium and iron chemistry in the O horizon changed by a shift in tree species composition. Biogeochemistry 2003, 63, 207-228.

16. Miles, J. Effect of Birch on Moorland. Cambridge: Natural Environment Research Council; Institute of Terrestrial Ecology, Banchory Research Station, Hill of Brathens, Glassel: Banchory, Scotland, 1981; p. 24.

17. Saetre, P.; Brandtberg, P.O.; Lundkvist, H.; Bengtsson, J. Soil organisms and carbon, nitrogen and phosphorus mineralization in Norway spruce and mixed Norway spruce-birch stands. Biol. Fertil. Soils 1999, 28, 382-388.

18. Priha, O.; Grayston, S.J.; Hiukka, R.; Pennanen, T.; Smolander, A. Microbial community structure and characteristics of the organic matter in soils under Pinus sylvestris, Picea abies and Betula pendula at two forest sites. Biol. Fertil. Soils 2001, 33, 17-24.

19. Saetre, P.; Bååth, E. Spatial variation and patterns of soil microbial community structure in a mixed spruce-birch stand. Soil Biol. Biochem. 2000, 32, 909-917.

20. Lavelle, P. Faunal activities and soil processes: Adaptive strategies that determine ecosystem function. In Transactions of the 15th World Congress on Soil Science; Etchevers, J.D., Aguilar, A., Nunez, R., Alcantar, G., Sanchez, P., Eds.; Society of Soil Science and Mexican Society of Soil Science: Mexico City, Mexico, 1994; pp. 189-220.

21. Brussaard, L. Soil fauna, guilds, functional groups and ecosystem processes. Appl. Soil Ecol. 1998, 9, 123-135.

22. Rothe, A.; Binkley, D. Nutritional interactions in mixed species forests: A synthesis. Can. J. For. Res. 2001, 31, 1855-1870.

23. Kienzler, M.; Alban, D.H.; Perala, D.A. Soil invertebrate and microbial populations under three species on the same soil type. USDA For. Serv. Res. Note NC-337; U.S. Dept. of Agriculture, Forest Service, North Central Forest Experiment Station: St. Paul, MN, USA, 1986; p. 4.

24. Frischbier, N. Untersuchungen zur einzelbaumverursachten kleinräumigen Variabilität und regenhöhenbasierten Dynamik des Bestandesniederschlages am Beispiel zweier Buchen-FichtenMischbestände. Ph.D. Thesis, Technische Universität Dresden, Germany, March 2012; p. 307.

25. Lindross, A.J.; Derome, J.; Derome, K.; Smolander, A. The effect of Scots pine, Norway spruce and silver birch on the chemical composition of stand throughfall and upper soil percolation water in northern Finland. Boreal Environ. Res. 2011, 16, 240-250.

26. Kimmins, H.; Blanco, J.A.; Seely, B.; Welham, C.; Scoullar, K. Forecasting Forest Futures. In $A$ Hybrid Modelling Approach to the Assessment of Sustainability of Forest Ecosystems and Their Values; Earthscan: London, UK; Washington, DC, USA, 2010.

27. Zinke, P.J. The pattern of influence of individual forest trees on soil properties. Ecology 1962, 43, 130-133.

28. Crampton, C.B. Podzolization of soils under individual tree canopies in southwestern British Columbia, Canada. Geoderma 1982, 28, 57-61.

29. Boettcher, S.E.; Kalisz, P.J. Single-tree influence on soil properties in the mountains of eastern Kentucky. Ecology 1990, 71, 1365-1372. 
30. Wagner, S. Einzelbaumeffekte-Eine Methode zur ökologischen Forschung in Mischbeständen. Berichte Freiburger Forstliche Forschung. In Beiträge zur Tagung 2004 der Sektion Waldbau DVFFA; Bauhus, J., Csapek, G., Eds.; Waldbau-Institut, Albert-Ludwigs-Unversity Freiburg: Göttingen, Germany, 2005; pp. 127-139.

31. Pretzsch, H. Forest Dynamics, Growth and Yield: From Measurement to Model; Springer: Berlin/Heidelberg, Germany, 2009; p. 664.

32. Schua, K. Standortsökologische Baumarteneffekte in einem Mischbestand aus Gemeiner Fichte (Picea abies [L.] Karst.) und Sand-Birke (Betula pendula Roth) im Erzgebirge. Ph.D.Thesis, Technische Universität Dresden, Germany, January 2012; p. 203.

33. Vance, E.D.; Brookes, P.C.; Jenkinson, D.S. An extraction method for measuring soil microbial biomass. Soil Biol. Biochem. 1987, 19, 703-707.

34. Joergensen, R.G. The fumigation-extraction method to estimate soil microbial biomass: Calibration of the kEC value. Soil Biol. Biochem. 1995, 28, 25-31.

35. Jenkinson, D.S.; Brookes, P.C.; Powlson, D.S. Measuring soil microbial biomass. Soil Biol. Biochem. 2004, 36, 5-7.

36. Isermeyer, H. Eine einfache Methode zur Bestimmung der Bodenatmung und der Karbonate im Boden. Z. Pflanzenernähr. Bodenkd. 1952, 56, 26-38.

37. Jäggi, W. Die Bestimmung der $\mathrm{CO}_{2}$-Bildung als $\mathrm{Maß}$ der bodenbiologischen Aktivität. Schweiz. Landwirtsch. Forsch. 1976, 15, 371-380.

38. Trüby, P; Aldinger, E. Eine Methode zur Bestimmung austauschbarer Kationen in Waldböden. Z. Pflanzenernähr. Bodenkde. 1989, 152, 301-306.

39. Zuur, A.F.; Ieno, E.N.; Walker, N.J.; Saveliev, A.A.; Smith, G.M. Mixed Effects Models and Extensions in Ecology with R; Springer Verlag: New York, NY, USA, 2009; p. 574.

40. Pinheiro, J.C.; Bates, D.M. Mixed-Effects Models in S and S-PLUS. In Statistics and Computing; Springer: New York, NY, USA, 2000; p. 528.

41. Hedderich, J.; Sachs, L. Angewandte Statistik; Springer Verlag: Berlin Heidelberg, Germany, 2012; p. 881 .

42. Jiménez Esquilín, A.E.; Stromberger, M.E.; Shepperd, W.D. Soil scarification and wildfire interactions and effects on microbial communities and carbon. Soil Sci. Soc. Am. J. 2008, 72, 111-118.

43. Busse, M.D.; Beattie, S.E.; Powers, R.F.; Sanchez, F.G.; Tiarks, A.E. Microbial community responses in forest mineral soil to compaction, organic matter removal, and vegetation control. Can. J. For. Res. 2006, 36, 577-588.

44. Phillips, R.P.; Fahey, T.J. The influence of soil fertility on rhizosphere effects in northern hardwood forest soils. Soil Sci. Soc. Am. J. 2008, 72, 453-461.

45. Hansson, K.; Olsson, B.A.; Olsson, M.; Johansson, U.; Berggren Kleja, D. Differences in soil properties in adjacent stands of Scots pine, Norway spruce and silver birch in SW Sweden. For. Ecol. Manag. 2011, 262, 522-530.

46. Smolander, A.; Kitunen, A. Soil microbial activities and characteristics of dissolved organic C and $\mathrm{N}$ in relation to tree species. Soil Biol. Biochem. 2002, 34, 651-660. 
47. Kanerva, S.; Kitunen, V.; Loponen, J.; Smolander, A. Phenolic compounds and terpenes in soil organic horizon layers under silver birch, Norway spruce and Scots pine. Biol. Fertil. Soils 2008, 44, 547-556.

48. Augusto, L.; Ranger, J.; Binkley, D.; Rothe, A. Impact of several common tree species of European temperate forest on soil fertility. Rev. Ann. For. Sci. 2002, 59, 233-253.

49. Huhta, V. Effects of liming and deciduous litter on earthworm (Lumbricidae) populations of a spruce forest, with an inoculation experiment on Allobophora caliginosa. Pedobiologia 1979, 19, 340-345.

50. Bredemeier, M.; Dohrenbusch, A.; Murach, D. Response of soil water chemistry and fine-roots to clean rain in a spruce forest ecosystem at Solling, FRG. Water Air Soil Pollut. 1995, 85, 1605-1611.

51. Quian, X.M.; Kottke, I.; Oberwinkler, F.; Kreutzer, K.; Weiss, T. Influence of liming and acidification on the activity of the mycorrhizal communities in a Picea abies (L.) Karst. stand. Plant Soil 1998, 199, 99-109.

52. Puhe, J. Die Wurzelentwicklung der Fichte (Picea abies) bei unterschiedlichen chemischen Bodenbedingungen. Ph.D. Thesis, Universität Göttingen, Germany, 1994; p. 128.

53. Sandnes, A.; Eldhuset, T.D.; Wollebæk, G. Organic acids in root exudates and soil solution of Norway spruce and silver birch. Soil Biol. Biochem. 2005, 37, 259-269.

54. Ammer, C.; Wagner, S. Problems and options in modelling fine-root biomass of single mature Norway spruce trees at given points from stand data. Can. J. For. Res. 2002, 32, 581-590.

55. Ammer, C.; Wagner, S. An approach for modelling the mean fine-root biomass of Norway spruce stands. Trees 2005, 19, 145-153.

56. Kalliokoski, T. Root System Traits of Norway Spruce, Scots Pine, and Silver Birch in Mixed Boreal Forests: An Analysis of Root Architecture, Morphology, and Anatomy. Ph.D. Thesis, University of Helsinki, Helsinki, Finland, June 2011; p. 67.

57. Menyailo, O.V.; Hungate, B.A.; Zech, W. Tree species mediated soil chemical changes in a Siberian artificial afforestation experiment. Plant Soil 2002, 242, 171-182.

58. Merilä, P.; Smolander, A.; Strömmer, R. Soil nitrogen transformations along a primary succession transect on the land uplift coast in western Finland. Soil Biol. Biochem. 2002, 34, 373-385.

59. Merilä, P.; Strömmer, R.; Fritze, H. Soil microbial activity and community structure along a primary succession transect on the land-uplift coast in western Finland. Soil Biol. Biochem. 2002, 34, 1647-1654.

60. Priha, O.; Smolander, A. Nitrogen transformations in soil under Pinus sylvestris, Picea abies and Betula pendula at two forest sites. Soil Biol. Biochem. 1999, 31, 965-977.

61. Frankland, J.C. Fungal succession-Unravelling the unpredictable. Mycol. Res. 1998, 102, 1-15.

62. Böttcher, J.; Springob, G. A carbon balance model for organic layers of acid forest soils. J. Plant Nutr. Soil Sci. 2001, 164, 399-405.

63. Brandtberg, P.O.; Bengtsson, J.; Lundkvist, H. Distributions of the capacity to take up nutrients by Betula spp. and Picea abies in mixed stands. For. Ecol. Manag. 2004, 198, 193-208.

64. Fischer, H.; Bens, O.; Hüttl, R.F. Veränderung von Humusform, -vorrat und -verteilung im Zuge von Waldumbau-Maßnahmen im Nordostdeutschen Tiefland. Forstwiss. Cent. bl. 2002, 121, 322-334. 
65. Schua, K.; Fischer, H.; Lehmann, B.; Wagner, S. Wirkungen einzelbaumweise eingemischter Trauben-Eichen (Quercus petraea (Matt.) Liebl.) auf den Oberbodenzustand in Kiefernbeständen (Pinus sylvestris L.). Allg. Forst- und Jagd.-Ztg. 2007, 178, 172-179.

66. Smolander, A.; Loponen, J.; Suominen, K.; Kitunen, V. Organic matter characteristics and C and $\mathrm{N}$ transformations in the humus layer under two tree species, Betula pendula and Picea abies. Soil Biol. Biochem. 2005, 37, 1309-1318.

67. Saetre, P. Spatial patterns of ground vegetation, soil microbial biomass and activity in a mixed spruce-birch stand. Ecography 1999, 22, 183-192.

68. Priha, O.; Smolander, A. Microbial biomass and activity in soil and litter under Pinus sylvestris, Picea abies and Betula pendula at originally similar field afforestation sites. Biol. Fertil. Soils 1997, $24,45-51$.

69. Kiikkilä, O.; Kitunen, V.; Smolander, A. Dissolved soil organic matter from surface organic horizons under birch and conifers: Degradation in relation to chemical characteristics. Soil Biol. Biochem. 2006, 38, 737-746.

70. Johansson, M.B. The chemical composition of needle and leaf litter from Scots pine, Norway spruce and white birch in Scandinavian forests. Forestry 1995, 68, 49-62.

71. Chauvat, M.; Titsch; D.; Zaytsev A.S.; Wolters, V. Changes in soil faunal assemblages during conservation from pure to mixed forest stands. For. Ecol. Manag. 2011, 262, 317-324.

72. Frischbier, N; Wagner, S. Detection, quantification and modelling of small-scale lateral translocation of throughfall in tree crowns of European beech (Fagus sylvatica L.) and Norway spruce (Picea abies (L.) Karst.). J. Hydrol. 2015, 522, 228-238.

73. Müller, K.H.; Wagner, S. Fine root dynamics in gaps of Norway spruce stands in the German Ore Mountains. Forestry 2003, 76, 149-158.

(C) 2015 by the authors; licensee MDPI, Basel, Switzerland. This article is an open access article distributed under the terms and conditions of the Creative Commons Attribution license (http://creativecommons.org/licenses/by/4.0/). 